\title{
Thomas William Drinkwater, Ph.D., L.R.C.P.E.,
}

$$
\text { L.R.C.S.E., F.I.C. }
$$

DR T. W. DRINKWATER died on January 25 , 1940, in his eighty-seventh year, almost realising his desire to finish his course "in harness." Born in Ireland in 1852 , he was educated at King's Lynn Grammar School, studied under Francis Sutton, Public Analyst, Norwich, with Professor A. J. Bernays at St Thomas's Hospital, London, and for a time in Germany. He came to Edinburgh as assistant to Dr (later Sir) Henry Littlejohn, Professor of Medical Jurisprudence, and for a time held the appointment of Chief Chemist with Messrs Hope \& Company, Leith Chemical Works. He qualified L.R.C.P.E., L.R.C.S.E., in 1877 , and from the year following until nearly the end of 1939 was Lecturer on Chemistry in the School of Medicine of the Royal Colleges of Physicians and Surgeons of Edinburgh. In 1928 he was the guest of honour at a dinner in Surgeons' Hall, given by the Fellows of the two Royal Colleges in celebration of his Jubilee as a Lecturer in the Edinburgh Medical School. He practised as an Analyst and Consultant in the City, and held appointments as Public Analyst for the counties of Ross and Cromarty, the Royal Burgh of Inverness, and the Burgh of Fortrose. He also acted as examiner in Chemistry for the Royal College of Physicians, the Royal College of Surgeons, and other bodies.

The foregoing presents a selection of facts, but does little to depict the man-familiarly and affectionately known as "Drinky" to students and colleagues alike. He was short and sturdy, with a smooth cleanshaven face which remained almost boyish despite advancing years; indeed a stranger recently observing his active movements and alert air in classroom or laboratory would have been astonished to learn that he had long passed "three score and ten."

The Doctor did not fail to keep in touch with modern developments, a fact well illustrated by the eagerness with which, a year or two ago, he sought the writer's advice regarding the installation of an Ultra-Violet Ray Lamp which he employed to demonstrate and apply some of the newest methods of fluorescence analysis.

Dr Drinkwater's interests outside his professional activities were many and varied, and included sport, photography, literature, and music. His after-dinner musical contributions were familiar, and many of us can recall him in this connection as author, vocalist, composer, and accompanist.

His fellow-lecturers miss their friend and colleague, who, though he had held office before most of them were born, leaves a memory of youthfulness both in outlook and appearance. In him were blended the intangible qualities which go to the making of a remarkable personality.

He was elected a Fellow in I90I.

C. N. K. 